\title{
ECONOMIA E SOCIEDADE NO CENTRO-OESTE BRASILEIRO DO SÉCULO XIX A PARTIR DA LEITURA DO ROMANCISTA BERNARDO GUIMARÃES
}

\author{
Economics and society in the Brazilian Central-West during the 19th century \\ based on the reading of the novelist Bernardo Guimarães
}

\author{
Márcio Bobik Braga \\ https://orcid.org/0000-0002-2582-0000 \\ Universidade de São Paulo, Programa de Pós-Graduação Integração da América Latina, São \\ Paulo, SP, Brasil. 05508-020 - prolam@usp.br
}

Resumo: O presente artigo tem como objetivo mostrar que as obras literárias regionalistas do escritor brasileiro Bernardo Joaquim da Silva Guimarães podem ser consideradas como fontes para estudos sobre a economia e a sociedade do hinterland central do Brasil no contexto da decadência da atividade de mineração do século XIX. Nelas, pode-se encontrar, por exemplo, a descrição da pobreza, escravidão e outros aspectos econômicos e sociais decorrentes do fim do ciclo da mineração, particularmente na Província de Minas Gerais, na região conhecida como Triângulo Mineiro e alto do Paranaíba, e Sul da Província de Goiás. Na pesquisa, foram considerados os romances $O$ Garimpeiro (2015), O Ermitão de Muquém (1958) e O Índio Afonso (1900) e os contos A Dança dos Ossos (2006a) e Uma História de Quilombolas (2006b). $\mathrm{O}$ artigo busca ainda contribuir para a relação entre a literatura e a história econômica que pode ser lida em inúmeras obras de autores brasileiros.

Palavras-chave: Bernardo Guimarães. Literatura e história econômica. A história econômica de Minas Gerais e Goiás.

Abstract: This article aims to show that the regionalist literary works of Bernardo Joaquim da Silva Guimarães, a Brazilian author, can be considered as a source for studies on the economy and society of the Brazilian central hinterland in the context of the decay of mining activity in the $19^{\text {th }}$ century. In these works, one can find the description of poverty, slavery and other economic and social consequences of the end of the mining cycle, particularly in the Province of Minas Gerais, in the region known as the Triangulo Mineiro and Alto do Paranaíba, and South of Goiás. The analysis focuses on the novels entitled $O$ Garimpeiro (2015), O Ermitão de Muquém (1958) and O Índio Afonso (1900), and on two short stories, A Dança dos Ossos (2006a) and Uma História de Quilombolas (2006b). The article also seeks to contribute to the study of the relationship between literature and economic history that can be found in numerous Brazilian authors.

Esta obra está licenciada sob uma Creative Commons - Atribuição 4.0 
Keywords: Bernardo Guimarães. Literature and economic history. The economic history of Minas Gerais and Goiás.

\section{Introdução}

Este artigo tem como objetivo mostrar que as obras de Bernardo Guimarães descrevem estruturas econômicas e sociais das províncias de Minas Gerais e Goiás no contexto da decadência da atividade de mineração no século XIX, colocando-as como fonte para estudos sobre a histórica econômica do Brasil. Esta hipótese é reforçada pela comparação dos relatos encontrados nos textos e aqueles discutidos pela historiografia. Na pesquisa, foram consideradas as seguintes obras do autor mineiro: $O$ Garimpeiro (GUIMARÃES, 2015), publicado originalmente em 1872, O Ermitão de Muquém (GUIMARÃES, 1958), de 1866, $O$ Índio Afonso (GUIMARÃES, 1900), de 1872 e os contos A Dança dos Ossos (GUIMARÃES, 2006a) e Uma História de Quilombolas (GUIMARÃES, 2006b), do livro Lendas e Romances, de 1871. O interesse aqui está voltado para o Sul de Goiás e Minas Gerais, nas regiões conhecidas como triângulo mineiro e alto do Paranaíba. ${ }^{1}$ Nas obras analisadas, é possível identificar informações sobre os meios de vida das populações das regiões como as atividades de subsistência, hábitos alimentares, produtos comercializados e relações de escravidão, dentre outros aspectos econômicos.

O escritor Bernardo Joaquim da Silva Guimarães nasceu em Ouro Preto no ano de 1825, e faleceu na mesma cidade em 1884. Formado em Direito pela Faculdade de Direito de São Paulo, no ano de 1852, passou a maior parte de sua vida em Minas Gerais, onde foi professor de retórica e poética, filosofia, latim e francês no Liceu Mineiro de Ouro Preto. Por duas vezes, entre os anos de 1852 - 1854 e 1861 - 1863, foi juiz municipal da cidade de Catalão, no Sul de Goiás. Apesar de ter exercido atividades profissionais como magistrado, jornalista e professor, dedicou-se principalmente à literatura regionalista. Inúmeros aspectos de sua biografia permitem atestar seu conhecimento acerca das regiões que descreve nos contos e romances. ${ }^{2}$

$\mathrm{O}$ artigo foi dividido em quatro seções, além desta introdução e das considerações finais. A primeira apresenta algumas questões metodológicas acerca da relação entre a história e a literatura, tomando como referência as obras de Bernardo Guimarães. A segunda considera a visão do escritor sobre as consequências da decadência da mineração em Minas Gerais a partir da leitura de $O$ Garimpeiro. A terceira busca evidenciar determinadas características das estruturas econômicas e sociais presentes na Província de Goiás a partir de O Ermintão de Muquém, O Índio Afonso e A Dança dos Ossos. A quarta trata de algumas relações escravistas que podem ser encontradas em Uma História de Quilombolas.

\footnotetext{
${ }^{1}$ A proximidade dessa região com Goiás justifica o Centro-Oeste presente no título do artigo.

${ }^{2}$ Essas e outras informações sobre a vida de Bernardo Guimarães foram retiradas de Magalhães (1926), ainda considerada a mais completa biografia do autor.
}

Anu. Lit., Florianópolis, v. 24, n. 2, p. 98-115, 2019. ISSNe 2175-7917 


\section{Literatura e história: notas metodológicas}

O século XIX se coloca, no Brasil, como um período privilegiado na relação entre a história e a literatura. Foi o momento em que os escritores brasileiros buscaram descrever, em suas obras, inúmeras características do país com a intenção de consolidar uma identidade nacional. Era necessário conhecer melhor a sociedade recém emancipada, particularmente as populações que viviam no vasto interior, pouco conhecido pelas elites letradas das grandes cidades litorâneas. Foi o momento em que, segundo Antonio Candido, o romance brasileiro buscou a verossimilhança da história e da sociologia a partir da descrição de "lugares, paisagens, cenas; épocas, acontecimentos; personagens-padrões, tipos sociais; quer no tempo (pelo romance histórico, que serviu de guia), quer no espaço" (CANDIDO, 1969, p. 111).

A necessidade que os escritores oitocentistas tinham em descrever a realidade do interior pode ser interpretada como a missão de incorporar o "sertão bruto" no processo de construção do Estado Nacional. Era uma forma de superar a herança colonial presente no "Brasil profundo" e que contrastava com o processo de modernização que se verificava nos espaços urbanos. Na maior parte do território brasileiro, a população ainda vivia as incerteza do abandono e do perigo da natureza em regiões onde não havia a proteção do Estado nem as facilidades materiais oferecidas pelo capitalismo embrionário ${ }^{3}$. Era necessário conhecer melhor o mundo rural longe do litoral. Nessa missão, destacou-se Bernardo Guimarães, um dos precursores do romance regionalista no Brasil. Em suas estórias, é possível encontrar situações que revelam o cotidiano das populações sertanejas do interior do país do século XIX. Conforme destacou Antonio Candido, as obras do escritor mineiro se caracterizam pela "boa prosa da roça, cadenciada pelo fumo de rolo que vai caindo no côncavo da mão ou pela marcha das bestas de viagem" (CANDIDO, 1969, p. 236). Tal caracterização expressa um estilo pitoresco, no qual se destacam representações detalhadas da relação do homem com a natureza construídas pela minuciosa observação e conhecimento do meio rural.

A leitura proposta neste artigo remete a análise à relação entre a história e a literatura. Apesar das diferenças entre o discurso literário e a narrativa histórica, eles podem ser complementares na descrição da realidade de uma época, possibilitando ao historiador fontes alternativas de pesquisa. Essa possibilidade foi considerada por Sandra Jatahy Pesavento:

A literatura é, pois, uma fonte para o historiador, mas privilegiada, porque lhe dará acesso ao imaginário, permitindo-lhe enxergar traços e pistas que outras fontes não lhe dariam. Fontes especialíssimas, porque lhe dá a ver, de forma por vezes cifrada, as imagens sensíveis do mundo. A literatura é narrativa que, de modo ancestral, pelo mito, pela poesia ou pela prosa romanesca fala ao mundo de forma indireta, metafórica e alegórica. Por vezes, a coerência de sentido que o texto literário apresenta é o suporte necessário para que o olhar do historiador se oriente para outras tantas fontes e nelas consiga enxergar aquilo que ainda não viu. (PESAVENTO, 2006, p. 22)

\footnotetext{
${ }^{3}$ Essa perspectiva é considera por Murari (2009), que analisa a relação entre a natureza e a literatura brasileira no século XIX.
}

Anu. Lit., Florianópolis, v. 24, n. 2, p. 98-115, 2019. ISSNe 2175-7917 
Para a historiadora, a literatura teria um efeito multiplicador de possibilidades que permite considerar algo a mais na pesquisa histórica ao evidenciar a imaginação de situações, ações, pensamentos e desejos das personagens em um determinado contexto histórico. Além disso, a narrativa literária representa uma memória que não necessariamente é compartilhada pelas gerações presentes. Essa perspectiva foi considerada pelo historiador Peter Burke no âmbito da História Cultural. Segundo ele, as memórias históricas, dentre elas aquelas que se encontram na literatura, sofrem modificações em decorrência das mudanças sociais e culturais que separam "o que somos daquilo que fomos":

À medida que os acontecimentos retrocedem no tempo, perdem algo de sua especificidade. Eles são elaborados, normalmente de forma inconsciente, e assim passam a se enquadrar nos esquemas gerais correntes na cultura. Esses esquemas ajudam a perpetuar as memórias, sob custo, porém, de sua distorção. (BURKE, 2008, p. 89)

Ou seja, a memória do escritor trata de um passado que não necessariamente é lembrado da mesma forma pelas gerações presentes. Nesse sentido, o texto literário pode ser entendido como um documento histórico específico elaborado a partir das experiências e reflexões do autor sobre a realidade que vivenciou ${ }^{4}$. Conforme será visto nas próximas seções, essa possibilidade pode ser encontrada no romance regionalista oitocentista, particularmente nas obras de Bernardo Guimarães, nas quais é possível ler inúmeros aspectos socioeconômicos e culturais presentes na relação entre as personagens de ficção e o meio rural.

Deve-se destacar que a verossimilhança da ficção pode ser atestada a partir da comparação dos relatos presentes no romance com algumas pesquisas realizadas por historiadores contemporâneos. Não se trata apenas de verificar a "verdade" da ficção a partir da narrativa histórica. A intertextualidade entre o literário e o histórico permite avaliar os procedimentos textuais pela identificação, em ambos, de "esquemas narrativos semelhantes e semelhantes esquemas de compreensão” (CARVALHAL, 1991, p. 13).

\section{A decadência da mineração e a pobreza em Minas Gerais de Bernardo Guimarães}

Estão presentes nos estudos da história do Brasil debates sobre determinadas características econômicas e sociais do hinterland brasileiro após o fím do ciclo da mineração. Para as províncias de Minas Gerais e Goiás, alguns historiadores consideram o aumento da pobreza como consequência marcante do fim da atividade mineradora. Autores como Celso Furtado e Caio Prado Jr., por exemplo, defendem a hipótese de que, após o ciclo da mineração, as duas regiões experimentaram forte decadência (FURTADO, 2000, p. 89-90; PRADO JR. 2000, p. 172-174). Porém, essa constatação não é consenso na historiografia quando se consideram os trabalhos de Sergio Buarque de Holanda e Jacob Gorender. Para esses autores, o processo teria ocorrido apenas em Goiás. Em Minas Gerais, a situação pós-crise teria sido de

\footnotetext{
${ }^{4}$ Sobre a especificidade do texto literário para a pesquisa histórica, ver Borges (2010).
} 
transição para uma economia agropecuária diversificada, cuja dinâmica era beneficiada pela crescente demanda por alimentos nas regiões cafeeiras e pelo crescimento das (HOLANDA, 1993, p. 292-294; GORENDER, 2016, p. 486-487). Não se tem a pretensão aqui de julgar uma ou outra interpretação como correta. Entretanto, parece prevalecer, nas narrativas de Bernardo Guimarães, a primeira para ambas as regiões.

As consequências da decadência da mineração podem ser analisadas a partir da leitura de O Garimpeiro, romance que se passa no interior de Minas Gerais, em sua parte sul, próxima às divisas de São Paulo e Goiás, entre as cidades de Uberaba, Bagagem (atual Estrela do Sul), Patrocínio e Araxá. A trama tem como núcleo central a relação entre Lúcia, a filha do Major, fazendeiro da região, e o vaqueiro Elias, da cidade de Uberaba. Deve-se destacar que, a despeito do título do romance, Elias, o principal protagonista, é na verdade descrito como um sertanejo.

O romance apresenta, no segundo capítulo, a descrição da festa religiosa denominada de Cavalhada, de origem portuguesa, que ocorre na Vila de Patrocínio e que até hoje é comemorada em algumas localidades do Sudeste e Centro-Sul do país. Há, na descrição, certo otimismo que acaba envolvendo o leitor. A festa agrega grande número de pessoas provenientes de outras regiões do país e se apresenta como uma oportunidade de negócios. Esse otimismo pode ser percebido na fala de Elias, principal cavaleiro da festa, quando se refere ao melhoramento de raças dos animais e ao desenvolvimento de novas habilidades no trato com o cavalo (GUIMARÃES, 2015, p. 30). Entretanto a festa é temporária e, com o seu fim, a região volta ao estado de isolamento e pobreza:

Acabada a festa, tudo caiu na tristeza e monotonia, não direi ordinária, porém muito pior ainda, pois contrastava horrivelmente com a alegria e festivo alvoroço dos dias atuais que acabavam de escoar-se, e dos quais somente restava a saudade.

Elias, de garboso e brilhante cavaleiro que era, passou a não ser mais que mero peão, isto é, voltou à sua condição de moço pobre e sem posição. (GUIMARÃES, 2015, p. 37)

A trama trata do amor impossível entre o pobre Elias e Lúcia, moça de uma família de posses. Entretanto, as posses eram apenas aparentes uma vez que seu pai, o Major, se encontrava endividado, buscando a sobrevivência na loteria do garimpo:

A Bagagem contava em seu seio talvez vinte mil almas à custa dos municípios
vizinhos, que ficaram despovoados. Quase todo o Patrocínio, o Araxá, grande
parte do Paracatu e Uberaba tinham-se mudado para as matas de bagagem.
O Major também não ficara isento da mania geral, e, tentado pelo demônio do
garimpo, deixou quase por completo abandono sua lavoura, e veio estabelecer-
se na Bagagem com sua família e quase toda a escravatura. (GUIMARÃES,
2015, p. 60-61)

Ou seja, a narrativa vai do otimismo ao pessimismo da decadência da mineração, que trouxe consequências negativas para a agropecuária em seu papel de ofertar alimentos para os trabalhadores no garimpo. Tal contexto é descrito no diálogo entre o Major e Leonel, pretendente de Lúcia, que se apresenta com próspero comerciante, mas que na verdade é um 
falsário de papel-moeda. Nesse diálogo, o Major, ao receber de Leonel o pedido de casamento da sua filha, revela-se como um decadente fazendeiro à beira da pobreza:

É a pura verdade; completamente arruinado. Este maldito garimpo, que seduz e cega o homem mais do que a mesa do jogo ou a meretriz artificiosa, tem-me devorado em pouco tempo todos os anos de trabalho na lavoura e no comércio sem a mínima compensação. Minha fazenda, meus escravos estão hipotecados, quase até o último, e em breve a miséria virá bater-me à porta. Desculpe-me esta franqueza; eu não devia ocultar-lhe as minhas circunstâncias, porque não me ficaria airoso dar-lhe a minha filha em casamento sem que o senhor soubesse que casava-se com a filha de um miserável. (GUIMARÃES, 2015, p. 69)

O Major, vendo-se em condição econômica adversa, pensa no casamento de Lúcia com Leonel como a única alternativa para a salvação de sua família da pobreza. Resta então a Elias buscar a sorte no garimpo e talvez ganhar algum dinheiro para tentar desfazer as intenções do Major. Nesse momento, a riqueza se sobrepõe ao amor e o sertanejo torna-se um pobre garimpeiro:

- Ah! Pobreza! Maldita pobreza! [...] Tu és o pior dos males que afligem a humanidade, pior que a fome, pior que a lepra, pior que a morte mesmo. De toda parte és repelida, como se foras um mal contagioso. Além de faltarem aos pobres todas as comodidades materiais da existência, são-lhe vedados todos os prazeres do coração. O pobre não pode, não deve amar... Ah! Se eu fosse rico!

... Por que não quis a sorte, que eu possuísse um pouco de dinheiro? Mas quem me impede de ter? [...] A Bagagem está ali perto... é um garimpo riquíssimo... pouco custa a cavar a terra, e lavar o cascalho. (GUIMARÃES, 2015, p. 46)

Pode-se perceber a ênfase que Bernardo Guimarães dá a pobreza na região. A decadência da lavoura leva tanto o Major quanto Elias à loteria do garimpo de ouro e diamantes. É importante destacar a preocupação das personagens: somente a riqueza seria a salvação do homem. Esse pensamento traduz o medo que pessoas pobres tinham da miséria e indigência em uma região desassistida pelo Estado.

No garimpo, Elias é enganado por Leonel. Porém, as atividades ilícitas do falsário são descobertas, resultando em sua prisão. Depois de quase perder o seu amor, o desfecho é feliz para Elias, que ganha de Simão, seu escravo, algumas pedras de diamantes e uma localização promissora para um pequeno garimpo. Elias encontra-se então com uma modesta riqueza, suficiente para casar-se com Lúcia e propiciar ao Major alguma tranquilidade em uma vida mais simples.

A pobreza descrita por Bernardo Guimarães não se resume ao fazendeiro, sertanejo ou garimpeiro. $\mathrm{O}$ escravo também era afetado. Com a falência ou morte dos fazendeiros, alguns alforriados não tinham como se sustentar, exceto pelo garimpo ou por algum outro patrão. Esse é o caso de Simão, ex-cativo do falecido pai de Elias. Apesar de Simão não ser tratado como escravo, sua submissão revela um tipo de escravidão de obediência e conformismo com a situação. Isso pode ser percebido no momento em que Elias parte para outra cidade para tentar

Anu. Lit., Florianópolis, v. 24, n. 2, p. 98-115, 2019. ISSNe 2175-7917 
o garimpo. Na despedida, Simão expressa sua angustia:

- Então Vmcê. vai-me deixar, patrão? - disse o velho, fitando em Elias olhos lastimosos. [...]

- Como hei de deixar-te aqui sozinho e desamparado!

- Não lhe dê isso cuidado. Ainda sei trabalhar. Deus é de misericórdia, e nunca há de faltar a este pobre velho um prato de feijão e um ranchinho em que durma. Já que é para o seu bem, vá meu patrão; Vmcê. não deve perder um lance de fortuna, que vem mesmo agora a talho de foice, por amor de um velho camarada, que já não é tão criança que não possa sir sozinho pelo mundo, e eu, a dizer a verdade, mais the iria servir de peso que de outra coisa.

- Contudo, Simão, não tenho ânimo de deixar-te assim. Se adoeceres...

- Não banze com isso. Tenho por aqui muito conhecimento, e muito patrão bem, que há de ter dó de mim. (GUIMARÃES, 2015, p. 58)

A partir dessa citação, pode-se imaginar o tipo de relação de escravidão naquela região. O escravo representava um alto custo para os fazendeiros falidos. Restava aos alforriados procurar na mineração o ganho para sua subsistência ou achar outro patrão. $O$ caso era particularmente preocupante no caso de Simão, tendo em vista sua avançada idade. O quadro de pobreza que prevalecia na região deixava o negro ou mestiço pobre sem muitas opções de sobrevivência. Esse quadro pode também ser observado nas atitudes da escrava Joana, que se dedicava aos trabalhos domésticos na fazenda do Major. Em uma conversa com Lúcia, Joana revela um desejo:

- Mas tu hoje és forra, Joana; deves ir cuidar na tua vida...

- Que importa isso?... Por acaso eu pedi alguma alforria? Entreguem-me cá a minha carta, e hão de ver como eu a faço em pedacinhos e atiro tudo no fogo. - Isso não Joana!... Tal não farás. Fui eu que pedi a meu pai te alforriasse, e sabes por quê?

- Eu sei lá!... De certo foi porque sinhazinha não me quer mais; quer ficar livre de mim.

- Pelo contrário, Joana, foi para não ficar sem ti. Se não fosses forra, irias cair nas mãos dos credores de meu pai, como todos os outros escravos da casa. (GUIMARÃES, 2015, p. 122)

Tem-se aqui uma situação peculiar: uma escrava que não quer a liberdade. O pai de Lúcia já havia transferido alguns dos seus escravos para os credores. Nessa situação, Lúcia insistia na alforria de Joana para não perder sua cuidadora. Trata-se de uma aparente contradição que pode ser explicada pelas condições econômicas adversas presentes na região.

\section{Economia e Sociedade no Interior de Goiás}

As consequências da decadência da atividade mineradora não ficaram restritas a Minas Gerais. Também foram sentidas em outras regiões do Centro-Oeste, particularmente em Goiás. Essa província teve algum dinamismo durante o ciclo da mineração ao longo do século XVIII; porém o esgotamento da atividade foi rápido, criando um quadro particular de pobreza 
manifestada pelas atividades de subsistência das populações. ${ }^{5}$ Essa percepção pode ser lida nas obras A Danças dos Ossos, O Ermitão de Muquém e O Índio Afonso.

Em A Danças dos Ossos, em que o autor é o narrador e protagonista, o sertão era um local de baixa densidade demográfica, com poucos povoados cercados por "profundas e vastas florestas que bordam as margens do Parnaíba, nos limites entre as províncias de Minas e Goiás" (GUIMARÃES, 2006a, p. 201-202). ${ }^{6}$ A trama do conto se passa em um porto no rio, que serve de limite entre as duas províncias e como local de descanso e alimentação dos viajantes de uma comitiva oficial.

Logo no início, o autor busca descrever seus companheiros sertanejos do Centro-Oeste:

Meus companheiros eram bons e robustos caboclos, dessa raça semi-selvática e nômade, de origem dúbia entre o indígena e o africano que vagueia pelas infindas florestas que correm ao longo do Parnaíba, e cujos nomes, de certo, não se acham inscritos nos assentos da freguesia, e nem figuram nas estatísticas que dão ao império... não sei quantos milhões de habitantes. (GUIMARÃES, 2006a, p. 203)

Se considerarmos a informação de que Bernardo Guimarães foi delegado em Catalão, esses companheiros provavelmente foram inspirados nos funcionários da delegacia e em viagens oficiais pela região. Tratava-se de uma população mestiça, pobre e com muitas crenças no convívio com o desconhecido. O conto gira em torno da estória contada pelo barqueiro do porto sobre ossos de um defunto que dançam à noite no caminho dentro da mata. Interessante aqui destacar a solidão e o medo em uma região na qual a lei e o poder de polícia são precários ou inexistentes, o que deixava os viajantes expostos à violência, percepção que também é compartilhada pela historiografia. ${ }^{7} \mathrm{O}$ conto evidencia ainda a pobreza e suas manifestações naquela região. Esse ponto pode ser percebido na fala do barqueiro, ao se desculpar com o chefe da comitiva pela ausência de peixe no jantar, já que ele não teria tido a oportunidade de comprar linha e anzol na vila pelo medo da noite (GUIMARÃES, 2006a, p. 205). Ou seja, a alimentação do barqueiro e da comitiva dependia da pesca local.

Já o romance $O$ Índio $A$ fonso $^{8}$ revela mais detalhes sobre a vida do sertanejo goiano, sua situação de pobreza, seus hábitos de alimentação e outras características do dia a dia das populações da província de Goiás. No texto, o autor caracteriza o sertanejo como pertencente a uma raça semi-selvática, não por preconceito, mas pelo seu estado de isolamento e esquecimento. O romance inicia com um cenário caracterizado pela ausência e medo: "as fundas e emmaranhadas selvas dos sertões de nossa terra, além das immensas riquezas e curiosidades naturaes que encerram, têm acobertado em sua sombra muito mysterio sinistro, muito negro drama de sangue e canibalismo" (GUIMARÃES, 1900, p. 11). A estória conta as

\footnotetext{
${ }^{5}$ Ver Prado Jr. (2000, p. 174).

${ }^{6}$ No conto, o autor comete o equívoco de nomear o rio de Parnaíba. Trata-se, na realidade, do rio Paranaíba.

${ }^{7}$ Ver, por exemplo, Souza (2006) e Silva et al. (2015).

${ }^{8}$ Por não estarem disponíveis edições posteriores do $O$ Índio Afonso, foi considerada aqui a edição de 1900 , publicado pela Editora Garnier. Nas citações, foi mantida grafia original, com as disparidades e incorreções da época.
} 
aventuras de Índio Afonso, foragido da polícia nas proximidades da Vila de Catalão. Apesar do seu apelido, ele era um sertanejo que "pertence a esta raça de índios mestiços que vivem vida nómade e semibarbara pelas margens dos grandes rios do sertão, subsistindo quasi exclusivamente de caça e pesca" (GUIMARÃES, 1900, p. 20).

Afonso era foragido da lei por matar um sujeito que teria molestado sua irmã. Depois do crime, ele se embrenha pelas matas que margeiam os rios como um aventureiro que sente prazer em fugir da polícia e mostrar seus conhecimentos da região, sem se preocupar com o precário poder das autoridades:

Todos sabem o que é a policia nessas vastas e desertas províncias do interior, quão inefficaz e impotente é para punir e reprimir o crime. A policia subalterna dos logarejos, essa - coitada ! - treme diante dos arreganhos de qualquer fanfarrão avalentoado, quando não pactua com elle.

O mais que pode fazer é levar o crime ao conhecimento do chefe de policia requisitando auxilio, que elle bem poucas vezes pôde prestar. Seria mister um numeroso exercito de policiaes para varejar aquellas vastas e invias mattas á cata de criminosos. Até que a denuncia chegue ás mãos do chefe de policia, já elles podem achar-se cem ou duzentas léguas do logar do delicto. (GUIMARÃES, 1900, p. 73-74)

O verdadeiro motivo da fuga não era o medo da polícia, mas a provável atitude de vingança por parte da família da vítima, ou pela delação de oportunistas em troca de algum favor das autoridades policiais. De qualquer forma, existia o medo da violência e era preciso estar preparado. Isso pode ser percebido pelos pertences do protagonista da estória:

De ordinário anda só, mas sempre armado, desde os pés até a cabeça, com excelentes armas, de que sabe usar com incrivel dextreza. Além de sua boa espingarda de dous canos, que nunca lhe sáe do punho, traz ao cinto duas pistolas de dous tiros, uma formidável garrucha, a indispensável faca e uma pequena fouce. (GUIMARÃES, 1900, p. 20)

Percebe-se que as armas não eram somente para a caça, mas também para a proteção. Em um ambiente hostil e sem a presença do poder público, a violência era motivo de constante preocupação, já que a região era povoada por "bandidos que até hoje tanto abundam infelizmente nas fronteiras centraes de nossas provincias, saltando de uma a outra para se esquivarem ás perseguições da policia" (GUIMARÃES, 1900, p. 27).

A polícia, quando presente, era precária. Essa condição pode ser percebida pelas ações dos dois soldados que conseguem encurralar Afonso em uma cachoeira. Enquanto Afonso se esconde na gruta atrás da queda das águas, os soldados ficam à espreita, porém sem muita pressa para realizar a prisão. A presença deles na beira do rio era algo a ser comemorado pela refeição disponível:

Vendo, pois, que lhes era impossível o ingresso n'aquelle horrendo escondrijo, depois de delibera vem por alguns minutos, resolveram que o melhor partido a tomar n'aquella conjunctura era ficarem de pé firme, fazendo sentinella viva á entrada da lapa, até que o fugitivo se resolvesse a sahir ou ficasse lá dentro morto de fome e frio. N'esse desígnio expediram dous companheiros á fazenda 
mais próxima, afim de irem procurar alguma provisão de bocca, ao menos sal, farinha e toucinho, pois havia peixe de sobra para abastecer-lhes fartamente a •cozinha. (GUIMARÃES, 1900, p. 103-104)

Depois do retorno dos companheiros, inicia-se a comemoração:

- Que belo! eim, camarada! dizia um delles no auge do enthusiasmo, haja cachaça, sal e farinha, que estou prompto a ticar aqui toda a minha vida.

- Também por minha parle póde Affonse ficar lá dentro de sua lapa quanto tempo quizer, que eu não darei o cavaco, antes lhe ficarei muito obrigado. [...] -Em lodo o caso permitia Deus que elle de la não saia ão cedo e que ao menos nos dê tempo de tomar um fartão de peixe. GUIMARÃES, 1900, p. 105-106)

A relação entre a euforia dos soldados e a refeição mais uma vez revela a intenção do autor em descrever a pobreza, que também afetava o precário poder público representado pelas forças policiais da região.

No texto, também é possível encontrar descrições dos hábitos alimentares das populações sertanejas que viviam na beira dos rios da região: caça e pesca, além de algum acompanhamento como farinha de milho ou mandioca, toucinho, sal e cachaça. Antes da fuga Afonso é servido por sua irmã, "uma excellente ceia, feijão, angú, peixe, palmitos e uma cabaça sortida de boa aguardente" (GUIMARÃES, 1900, p. 65). Aqui fica claro que se tratava de uma região que vivia quase que exclusivamente das atividades básicas de subsistência. Havia também uma precária pecuária. As criações de gado eram realizadas pelos campos de Catalão e Santa Luzia, em fazendas cercadas de um pequeno povoado à beira de algum importante rio. Não havia cercas, mas somente a mata como limite. As rés eram dispersas por grandes campinas e em geral não eram contadas pelos proprietários (GUIMARÃES, 1900, p. 21-22).

Nas leituras até aqui realizadas, destacou-se uma estrutura econômica sem qualquer dinamismo. Entretanto, é possível encontrar atividades de comércio no romance $O$ Ermitão de Muquém, ${ }^{9}$ em que Bernardo Guimarães narra a história das origens da Romaria de Nossa Senhora de Abadia de Muquém, que até hoje ocorre na cidade de Goiás Velho.

Logo no início do romance, o autor caracteriza a região como desértica e esquecida, mas que ganha alguma dinâmica com a romaria:

Lá bem longe, no coração dos desertos, em uma das mais remotas e despovoadas províncias do Império, existe uma das mais notáveis e concorridas dessas romarias, notável, sobretudo, se atendermos ao sítio longínquo e às enormes distâncias que os romeiros têm de percorrer para chegar ao solitário e triste vale em que se acha erigida a capelinha de Nossa Senhora da Abadia do Muquém, na província de Goiás (GUIMARÃES, 1958, p. 10).

Ou seja, tratava-se de um lugar com baixa densidade populacional, porém com uma potencial fonte de dinamismo econômico proporcionado pelo evento religioso, que atraia pessoas de outras cidades ou mesmo de outras províncias. $\mathrm{O}$ aumento da população durante o

\footnotetext{
${ }^{9}$ Para as citações aqui consideradas, utilizou-se a edição de 1958, como a estrutura gramatical da época.
} 
evento já seria suficiente para incentivar algum comércio. Isso é destacado no início do romance:

[...] aquele lugar, completamente desabitado no fundo dos sertões, onde apenas existe uma capelinha e um casebre sem habitante, converte-se de repente em uma cidade cheia de vida, de rumor e movimento, composta de barracas, toldos, carros de bois e ranchos coberto de capim. Reúne-se ali todos os anos, na época da festa, uma população de cêrca de 10 mil pessoas, que vêm de distâncias enormes, até o Pará e Rio Grande do Sul, uma por devoção e para cumprir promessas, outras para fazerem comércio, pois que nesses dias aquele lugar torna-se uma feira imensa, onde se compra, vende-se e permutase tôda a qualidade de mercadorias. Aí os sertanejos do norte e maranhão, vãose prover de fazendas, quinquilharias, ferragens e vinhos, que compram aos negociantes de Meia-Ponte e Goiás, que conduzem daquele ponto essas mercadorias. Os romeiros também vendem aos negociantes destas duas cidades aos de Minas e São Paulo, grande quantidade de couros, solas, animais cavalares, rêdes fabricadas pelos índios, escravos, ouro em pó e diamantes. (GUIMARÃES, 1958, p. 12)

O romance também descreve os produtos provenientes de outras regiões que, mesmo sendo para as oferendas religiosas, provavelmente seriam vendidas aos devotos:

A quinze de agosto, dia em que se celebra a festa da Santa, uma imensa multidão, que acudida de todos os cantos da capitania de Goiás, e mesmo das capitanias vizinhas, vinham reunir-se em tôrno da capelinha de Muquém [...]. Nessa quadra as mal trilhadas e solitárias sendas, que dos diversos pontos da província da província conduzem à isolada ermida, viam-se apinhadas de viandantes, de tôdas as classes, sexos e idades, que iam em devota romaria cumprir suas promessas, levando preciosos presentes em dinheiro, escravos, gado, animais, objetos de ouro e prata, cera, paramentos, alfaias e mil outras coisas. (GUIMARÃES, 1958, p. 155)

O comércio também envolvia algumas populações indígenas. Esse era o caso dos denominados $\operatorname{Coroados}^{10}$, que: "começavam a entreter relações de amizade e de comércio com os goianos. Algumas hordas dêstes selvagens já começavam a ir a Goiás vender esteiras, peles, guaraná e outros objetos, e comprar armas, ferramentas, fazendas e quinquilharias" (GUIMARÃES, 1958, p. 60-61).

Em suma, a leitura do romance $O$ Ermitão de Muquém permite ao leitor notar a existência de um mercado interno, ainda que precário e sazonal, fora do sistema primário-exportador brasileiro, entre a localidade da romaria e outras regiões de Goiás ou mesmo de outras províncias. Também é possível visualizar os bens comercializados: tecidos, peles, escravos, ouro e diamantes (como forma de pagamento), ferramentas em geral (incluindo ferramentas para a produção agrícola), armas, sal, cachaça, fumo e café, dentre outros produtos. Interessante notar a demanda dos índios: armas para a proteção ou guerra contra outras tribos ou capitães do mato.

\footnotetext{
${ }^{10}$ Os Corados era a denominação utilizada para representar os índios que usavam algum tipo de coroa na cabeça. No caso de Goiás, esses índios da tribo dos Caiapós.
} 
O romance reforça ainda uma característica social marcante naquela região e que também está presente em A Dança dos Ossos e em O Índio Afonso. A estória conta como Gonçalo, sertanejo do interior de Goiás, torna-se o famoso ermitão. Em festa em um bordel, Gonçalo comete um crime violento sem motivo aparente. Após a barbárie, ele foge de possíveis vingadores e da polícia (GUIMARÃES, 1958, p. 59). Trata-se de uma estória parecida com a do Índio Afonso, exceto por considerar um sertanejo bandido, muito semelhante ao jagunço nordestino:

Demais, Gonçalo tinha por si grande número de parceiros, vadios e bandidos como êle, que o temiam e respeitavam, e com os quais contava em ocasião de aperto. Era uma malta de rapazes ociosos e devassos, da qual êle, por sua superioridade em forças, destreza, riqueza e generosidade, era o chefe natural. (GUIMARÃES, 1958, p. 20)

Em sua fuga, Gonçalo parte para uma região desconhecida no norte da província. Em um determinado momento, o fugitivo depara-se com os índios da tribo dos Xavantes, que "mal conheciam os brancos, com quem não queriam relação alguma e que odiavam do fundo da alma" (GUIMARÃES, 1958, p. 47). Preparado para um possível confronto, Gonçalo carregava por aquelas selvas um arsenal de armas:

Ali, encostou todo o seu arsenal de armas, que consistiam em um arco com algumas flechas, uma grande faca, uma foice pequena, uma pistola de dois canos e uma espingarda carregada com os últimos cartuchos que lhe restavam, e que de propósito reservara para ocasiões difíceis. (GUIMARÃES, 1958, p. 51)

Pode-se notar que Gonçalo também possuía arcos e flechas, uma descrição simbólica para sua condição semi-selvática. Esse e outros relatos confirmam a existência, nas regiões consideradas por Bernardo Guimarães, de "vadios e bandidos" que levavam o medo às populações rurais.

Retomando a questão alimentar, o romance descreve um conjunto de produtos que faziam parte da alimentação dos sertanejos de Goiás: feijão com toucinho, linguiças assadas, arroz, aguardente de cana, "para cortar os efeitos desses alimentos pesados e gordurosos" (GUIMARÃES, 1958, p. 13) e o café, que o autor faz questão de especificar, como se desejasse realizar uma propaganda sobre o produto e seus benefícios na segunda metade do século XIX:

Por fim, tomou-se o café, não essa tintura negra e detestável que se serve por aí [...], mas o verdadeiro café aromático ou balsâmico, tal como se sabe preparar em Minas, e cujos deliciosos vapores aquecem o cérebro e expande, tão suavemente, o coração. (GUIMARÃES, 1958, p. 13-14).

Em vários de seus textos, Bernardo Guimarães destaca o uso popular da cachaça. Em $A$ Dança dos Ossos, por exemplo, a embriaguez do balseiro pela bebida seria a explicação para a alucinação dos ossos dançantes. Em O Ermitão de Muquém, antes do crime a ser cometido por Gonçalo, havia uma festa onde a "aguardente de cana e outros licores circulavam com abundância” (GUIMARÃES, 1958, p. 23).

Anu. Lit., Florianópolis, v. 24, n. 2, p. 98-115, 2019. ISSNe 2175-7917 
Também são citados no romance, alimentos como peixes e animais de caça, palmitos, mandioca, mel de jataí, ovos de tartaruga, frutos silvestres e o suave licor extraído do tronco do buriti, além do guaraná, "cuja composição até hoje se ignora o segrêdo" (GUIMARÃES, 1958, p. 71). Nota-se que boa parte dos produtos é de origem local e provenientes de coletas.

Enfim, a partir dessas leituras, é possível perceber um vasto conjunto de informações sobre importantes aspectos da vida econômica e social em Goiás, província povoada por negros escravos, índios e mestiços ou sertanejos esquecidos pela Corte.

\section{Os quilombos de Minas: visões sobre a escravidão em Bernardo Guimarães}

Quando se fala em escravidão no pensamento de Bernardo Guimarães, logo surge na imaginação o romance A Escrava Isaura, uma das histórias mais populares do Brasil e no mundo, principalmente pela repercussão da adaptação do texto para a televisão, que teve boa acolhida em inúmeros países. O tema da escravidão, entretanto, é tratado em várias outras obras do autor.

Com já enfatizado, o negro, o mestiço e o escravo fazem parte, direta ou indiretamente, das estórias de Bernardo Guimarães. Tais referências, em uma simplificação exagerada, mas necessária para compreender o pensamento do autor sobre o tema, leva a dois tipos de relação de escravidão. O primeiro baseia-se em algum grau de "cooperação" entre o senhor e o escravo, além do conformismo deste em relação à situação, conforme a leitura da obra $O$ Garimpeiro aqui realizada. O segundo tipo pode ser encontrado no conto Uma História de Quilombolas, em que o modo de produção escravista era bem mais violento. A narrativa traz ainda informações relevantes que contemplam aspectos econômicos e mesmo políticos em torno dos quilombos de Minas Gerais.

O conto começa com uma visão geral do que seria a população de quilombolas:

Naqueles tempos, na província de Minas, desde a serra da Mantiqueira até os confins dos terrenos diamantinos, era uma série de quilombos, que eram o flagelo dos tropeiros e dos caminhantes, e o terror do fazendeiro. As milícias e os capitães-do-mato do governador, a despeito dos esforços que empregavam, eram impotentes para dar cabo deles. Eram como formigueiros; se aqui extinguia-se um, acolá organizava-se outro com os restos daquele e com uma chusma de outros negros, que incessantemente fugiam a seus senhores, certos de achar agasalho e vida regalada nos covis de seus parceiros quilombolas. (GUIMARÃES, 2006b, p. 10)

A formação de quilombos como formigueiros confirma a existência de um grande número de escravos durante o período de mineração em Minas Gerais, evidência que pode ser confirmada a partir de dados apresentados por Gorender (2016, p. 484). As fugas também sugerem certo grau de violência em determinadas formas de escravidão, diferente daquelas descritas em $O$ Garimpeiro: para o negro, era melhor aceitar a incerteza da fuga e dos capitães do mato ao cativeiro.

A divisão que pode ser lida nas obras de Bernardo Guimarães foi considerada por Roger

Anu. Lit., Florianópolis, v. 24, n. 2, p. 98-115, 2019. ISSNe 2175-7917 
Bastide em Brasil, Terra de Contrastes quando afirma que, em Minas Gerais, a escravidão teria assumido duas formas. Teria sido "ao mesmo tempo mais rude e mais suave", ao contrário do Nordeste, onde as formas eram mais homogêneas e violentas (BAPTISTE, 1973, p. 116). Essa divisão é questionada por pesquisas mais recentes, como aquela realizada por Carlos Magno Guimarães, que nega a existência de uma escravidão "suave" em Minas a partir de informações sobre o conflito entre quilombolas, fazendeiros e autoridades. Entretanto, este autor reconhece algumas contradições como a submissão de escravos aos senhores motivados pela proteção. $\mathrm{O}$ autor destaca ainda que muitos escravos possuíam armas e mesmo assim não se rebelavam contra os seus patrões (GUIMARÃES, 1996, p. 144). ${ }^{11}$

O conto trata das aventuras de Anselmo, que vê sua noiva Florinda ser sequestrada por Mateus, um escravo mestiço que foge do cativeiro na fazenda e vai para o Quilombo de Zambi Casagrande, no sertão mineiro próximo da cidade de Vila Rica. ${ }^{12}$ Florinda, mestiça, era filha de uma escrava e protegida do fazendeiro, denominado de Capitão (conhecido apenas pelo título, como o Major de $O$ Garimpeiro). Anselmo, ao tentar resgatar Florinda, acaba nas mãos dos quilombolas. Interessante notar que as personagens eram na verdade mestiços. Mateus, por exemplo, é aceito com desconfiança por Zambi por não ser negro puro.

No conto, o autor destaca alguns detalhes da vida dos quilombolas. Em primeiro lugar, tratava-se de uma vida de relativa fartura, seja na alimentação ou na utilização de artigos de luxo importados. O texto descreve os seguintes produtos consumidos pelos quilombolas: carne, presunto, azeitonas, bolachas, toucinho, farinha, sal, vinho, cerveja, café, tabaco e pango ${ }^{13}$, além de gêneros alimentícios e bebidas proveniente das várias regiões do país (GUIMARÃES, 2006b, p. 41). Essa descrição pode ser confirmada pela minuciosa pesquisa realizada pela historiadora Sônia Maria de Magalhães sobre o padrão de consumo alimentar em Minas Gerais nos séculos XVIII e XIX (MAGALHÃES, 2004). Muitos desses produtos eram provenientes de assaltos realizados nas fazendas vizinhas (GUIMARÃES, 2006b, p. 40). A região onde aconteciam os roubos era dividida entre os quilombos, que estabeleciam "reservas de mercado" ao proibir ações em determinadas localidades ou fazendas. Mas havia também o comércio legal:

Os quilombos tinham de feito intermediários que especulavam com eles, e por meio dos quais faziam grandes transações de compra e venda, e esses intermediários, não poucas vezes, eram pessoas que gozavam de vantajosa posição na sociedade" (GUIMARÃES, 2006b, p. 83).

Nesta citação, destaca-se a relação entre os quilombos com parte da elite econômica e política da região. Mas não apenas. Quando Anselmo inicia sua jornada para resgatar Florinda do Quilombo de Zambi, não aceita a ajuda proposta pelo senhor de Florinda, que se oferece para interceder junto ao Governador de Vila Rica:

\footnotetext{
${ }^{11}$ Sobre a escravidão de "submissão", ver também Chalhoub (2012).

${ }^{12}$ Zambi na verdade era o nome adotado pelos chefes dos quilombos. Zumbi dos palmares era também um Zambi. Também pode ser entendido como "Deus Supremo", segundo o dicionário Houaiss.

${ }^{13}$ Essa expressão se refere ao denominado "pito do pango", designação para a maconha, e que usada pelo chefe do quilombo.
} 
- É tempo perdido, senhor capitão. Há muita gente graúda que capeia esses malditos e se enriquece por meio deles. Não falta quem os avise, e nunca podem ser agarrados. Se nós mesmos não fizemos diligências, e nos fiarmos no governo de Vila Rica, estamos bem aviados. (GUIMARÃES, 2006b, p. 18)

Tratava-se de uma prática de alianças entre senhores, autoridades políticas e quilombolas, seja por motivações econômicas em decorrência do comércio, evidência que pode ser encontrada na pesquisa de Carlos Magno Guimarães (GUIMARÃES, 1996, p. 153-154). O diálogo mostra a velha história da corrupção, que se estabeleceu em lugares e tempos inimagináveis.

No final da trama, Anselmo e Zambi se salvam da quase inevitável morte e apertam as mãos em "um protesto tácito e mútuo estima e lealdade para sempre" (GUIMARÃES, 2006b, p. 115). Nessa passagem, Bernardo Guimarães se revela otimista em relação à cooperação entre quilombolas e "outras sociedades" do interior do país, destacando de forma simbólica sua posição abolicionista.

\section{Considerações finais}

Este artigo teve como objetivo analisar as obras de Bernardo Guimarães sob o ponto de vista da história econômica do Brasil. Considerado um dos precursores da literatura regionalista, o escritor mineiro fez parte de um grupo de autores oitocentistas que buscaram descrever o vasto e quase deserto interior do país. Seus contos e romances foram concebidos em um momento em que a literatura buscava considerar, na ficção, aspectos econômicos, sociais e culturais compartilhados pela sociedade brasileira. Tratava-se de uma missão cujo objetivo era subsidiar as elites letradas no exercício da interpretação das velhas e novas estruturas de uma nação recém emancipada. Esse esforço também produziu inúmeras informações relevantes para a historiografia.

Nas leituras realizadas neste artigo, foi possível visualizar vários aspectos do cotidiano das populações rurais do Sul de Goiás e do Triângulo Mineiro no contexto da decadência do ciclo da mineração, que se intensifica no século XIX. Em um mundo de privações materiais, fazendeiros falidos, pobres sertanejos, escravos, índios e quilombolas tentavam sobreviver em regiões onde não existia o poder público ou qualquer amparo legal. Muitos exerciam algum comércio, além de atividades de subsistência, incluindo a caça, a pesca e a coleta, como forma de sobrevivência em meio da pobreza e precariedade das forças policiais. Também foi possível a visualização de padrões de consumo alimentar, o que contribui a reconstrução das atividades econômicas nas regiões consideradas. São informações valiosas para a historiografia, particularmente quando são escassas as fontes primárias de pesquisa. $\mathrm{O}$ artigo buscou comparar, ainda que de forma breve, tendo em vista a limitação de espaço, os relatos contidos nas estórias e as descrições realizadas por alguns historiadores contemporâneos, o que permitiu reforçar a verossimilhança do mundo das personagens de ficção. Sob uma perspectiva mais ampla, o artigo buscou contribuir para estudos que contemplam a relação entre a literatura e a história 
econômica do Brasil oitocentista. Trata-se de uma importante possibilidade metodológica que se coloca diante de um vasto campo de pesquisa interdisciplinar.

\section{Referências}

BAPTISTE, Roger. Brasil, Terra de Contrastes. 5. ed. São Paulo: Difusão Europeia do Livro, 1973.

BORGES, Valdeci Rezende. História e literatura: algumas considerações. Revista de Teoria da História. Goiânia, ano 1, n. 3, p. 94-110, jun. 2010.

BURKE, Peter. O que é História Cultural? Tradução de Sergio Goes de Paula. 2. ed. Rio de Janeiro: Zahar, 2008.

CANDIDO, Antonio. Formação da literatura brasileira: momentos decisivos. Vol. 2, 3. ed. Rio de Janeiro: Martins Editora, 1969.

CARVALHAL, Tânia Franco. Literatura comparada: a estratégia interdisciplinar. Revista Brasileira de Literatura Comparada. Porto Alegre, v. 1, n. 1, p. 9-21, 1991.

CHALHOUB, Sidney. População e Sociedade. In: CARVALHO, José Murilo. A Construção Nacional: 1830-1889. Rio de Janeiro: Objetiva, 2012, p. 37-81.

FURTADO, Celso. Formação Econômica do Brasil. 27. ed. São Paulo: Companhia Editora Nacional/ Publifolha, 2000.

GORENDER, Jacob. O Escravismo Colonial. 6. ed. São Paulo: Expressão Popular, 2016.

GUIMARÃES, Bernardo. O Índio Afonso. Rio de Janeiro: Typografia Garnier, 1900.

GUIMARÃES, Bernardo. O Ermitão de Muquém: História da fundação da Romaria de Muquém na Província de Goiás. São Paulo: Edições Melhoramentos, 1958.

GUIMARÃES, Bernardo. A Dança dos Ossos. In: GUIMARÃES, Bernardo. Lendas e Romances. 4. ed. São Paulo: Editora Martins Fontes, 2006a, p. 199-235.

GUIMARÃES, Bernardo. Uma História de Quilombolas. In: GUIMARÃES, Bernardo. Lendas e Romances. 4. ed. São Paulo: Editora Martins Fontes, 2006b, p. 3-141.

GUIMARÃES, Bernardo. O Garimpeiro. São Paulo: Martin Claret, 2015.

GUIMARÃES, Carlos Magno. Mineração, Quilombos e Palmares. In: REIS, João; GOMES, Flávio dos Santos. Liberdade por Um Fio: História dos Quilombos no Brasil. São Paulo: Companhia das Letras, 1996, p. 139-163.

HOLANDA, Sérgio Buarque. História Geral da Civilização Brasileira: A Época Colonial Administração, Economia e Sociedade, tomo I, 2 v., 7. ed. São Paulo: Editora Bertrand Brasil S.A., 1993. 
MAGALHÃES, Basílio de. Bernardo Guimarães: esboço biographico e critico. Rio de Janeiro: Tipographia do Annuario do Brasil, 1926.

MAGALHÃES, Sônia Maria. A Mesa de Mariana: produção e consumo de alimentos em Minas Gerais. São Paulo: Annablume, 2004.

MURARI, Luciana. Natureza e Cultura no Brasil (1870 - 1922). São Paulo: Alameda, 2009.

PESAVENTO, Sandra Jatahy. História \& Literatura: uma velha nova história. In: COSTA, Cléria Botelho da; MACHADO, Maria Clara Tomaz (Org.). História \& Literatura: identidades e fronteiras. Uberlândia: Universidade Federal de Uberlândia, 2006, p. 11-27.

PRADO JR. Caio. Formação do Brasil Contemporâneo. São Paulo: Brasiliense; Publifolha, 2000 .

SILVA, Sandro Dutra et al. A Terra dos Coronéis no Oeste do Brasil: a Cattle Frontier, Violência e Dominação Fundiária no Cerrado Goiano. Revista Topoi, Rio de Janeiro, v. 16, n. 30, p. 234-259, jan./jun 2015.

SOUZA, Dalva Maria Borges de Lima Dias de. Violência, Poder e Autoridade em Goiás. Goiânia: UFG, 2006.

\section{NOTAS DE AUTORIA}

Márcio Bobik Braga (marbobik@usp.br) é professor Livre-Docente do Departamento de Economia da Universidade de São Paulo - campus de Ribeirão Preto - FEA-RP/USP, e pesquisador do Programa Multidisciplinar de Pós-Graduação em Integração da América Latina - PROLAM/USP. É Autor dos livros: "Integração e Desenvolvimento na América Latina: A Contribuição de Raul Prebisch e da CEPAL", publicado pela Editora AnnaBlume, e "A Nova Contabilidade Social", publicado pela Editora Saraiva, em coautoria com Leda Maria Paulani. Tem como área de pesquisa a literatura e a história econômica na América Latina.

\section{Como citar esse artigo de acordo com as normas da revista}

BRAGA, Márcio Bobik. Economia e sociedade no Centro-Oeste brasileiro do século XIX a partir da leitura do romancista Bernardo Guimarães. Anuário de Literatura, Florianópolis, v. 24, n. 2, p. 98-115, 2019.

\section{Contribuição de autoria}

Não se aplica.

\section{Financiamento}

Não se aplica.

\section{Consentimento de uso de imagem}

Não se aplica. 
Aprovação de comitê de ética em pesquisa

Não se aplica.

\section{Licença de uso}

Este artigo está licenciado sob a Licença Creative Commons CC-BY. Com essa licença você pode compartilhar, adaptar, criar para qualquer fim, desde que atribua a autoria da obra.

\section{Histórico}

Recebido em: 20/02/2019

Revisões requeridas em: 15/07/2019

Aprovado em: 25/07/2019

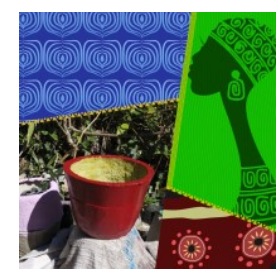

